\title{
Návratová migrace, reemigrace nebo etnická návratová migrace? \\ Potomci krajanů ze západní Ukrajiny a z jižní Moldávie a jejich dưvody migrace do České republiky
}

\author{
Luděk Jirka
}

\author{
DOI: 10.21104/CL.2020.2.05 \\ Return Migration, Re-emigration or Ethnic Return Migration? \\ Diasporic descendants from West Ukraine and South Moldova \\ and Their Reasons for Migration into the Czech Republic
}

\begin{abstract}
The terms 'return migration' or 're-emigration' deal with the return of the diaspora to the country of origin and are therefore full of nationalistic perspective. These terms can be useful in the case of a diasporic return to the country of origin, however, the use of the term 'ethnic return migration' should be clarified as well becaus migration of diasporic descendants (to the country of origin of their ancestors) by strategic, rational and pragmatic use of their ethnic disposition (i.e. passports of their ancestors with written nationality) should also be looked into. Indeed, term ethnic return migration expresses that in the case of some diasporic descendants their ethnic origin might be lost and the diasporic identification questioned hence their migration to the country of origin of their ancestors could be analysed as mobility for material or economic benefit. In this article I will analyse the migration of diasporic descendants from West Ukraine and South Moldova to find out whether they incline more to return migration/ re-emigration or to ethnic return migration.
\end{abstract}

\section{Key words}

return migration, re-emigration, ethnic return migration, diasporic descendants, Moldova, Ukraine, diasporic consciousness

\section{Acknowledgment}

Rád bych na tomto místě poděkoval třem anonymním recenzentům i šéfredaktorce Českého lidu Janě Noskové, jejichž věcná kritika přispěla ke zkvalitnění článku.

\section{Contact}

Mgr. Luděk Jirka, Ph.D., Katedra kulturních a náboženských studií, Pedagogická fakulta, Univerzita Hradec Králové, Víta Nejedlého 573/4, Slezské Předměstí, 50003 Hradec Králové, Czech Republic; e-mail: ludek.jirka@uhk.cz.

\section{Jak citovat / How to cite}

Jirka, Luděk. (2020). Návratová migrace, reemigrace nebo etnická návratová migrace? Potomci krajanů ze západní Ukrajiny a z jižní Moldávie a jejich důvody migrace do České republiky. Český lid 107, 211-229. doi:http:// dx.doi.org/10.21104/CL.2020.2.05 


\section{Úvod}

Termíny návratová migrace a reemigrace jsou v českých sociálních vědách poměrně široce užívané. Spojovány jsou s poválečnou migrací krajanů z východní, střední a jihovýchodní Evropy do Československa (Vaculík 1984; 2002; Heroldová 1992), ale také s migrací tzv. černobylských krajanů (osob postižených černobylskou katastrofou) do České a Slovenské Federativní Republiky, respektive do České republiky v letech 1991-1993 (Valášková 1992; Dluhošová 1992; Jánská - Drbohlav 2001; Šolcová 2012). Uvedené termíny se také spojují s nedávnou migrací krajanů z východní i z jižní Ukrajiny do České republiky, kteří přišli v roce 2015 v důsledku válečného konfliktu na východní Ukrajině. ${ }^{1}$ Ve všech uvedených př́padech na krajany dopadá význam termínů návratová migrace/reemigrace i s jejich nacionalizačním náhledem, který krajanům přikládá sounáležitost s českým národem. Termíny návratová migrace/reemigrace totiž obecně předpokládají krajanský pocit př́slušnosti k českému národu (viz také Safran 1991; Cohen 1997), což je často vnímáno i jako jeden z důležitých aspektů jejich návratu (např. Bělohradská 2008). Předpoklad krajanského národního vědomí však opomíjí významnou problematiku - krajané i jejich potomci jsou v českém prostředí souhrnně vnímáni jako nositelé národního vědomí.

V souvislosti s tímto problémem budu odkazovat na zahraniční badatele a na jejich termín etnická návratová migrace - ethnic return migration ${ }^{2}$ (Fox 2003; 2007; Joppke 2005; Joppke - Rosenhek 2009; Tsuda 2001; 2003; 2009; 2010; Skrentny et al. 2007; Brubaker 1998), který znamená „reemigraci“ potomků diaspory (anglicky diasporic descendants), kteří jsou již plně asimilováni v zemi svého narození a kteří již ztratili kulturní i etnické vědomí předků (Tsuda 2009). ${ }^{3}$ Využití předků za účelem „reemigrace“ pak může být interpretováno jako racionální, strategický, pragmatický nebo instrumentální kalkul těchto jedinců, který je ale umožněn díky př́ivětivé imigrační politice určitých států vůči diaspoře. Pojmy návratová migrace/reemigrace a etnická návratová migrace sice mohou znít podobně, ale existuje mezi nimi významný metodologický rozdíl - zatímco návratová migrace/reemigrace předpokládá identifikaci s (českým) národem, etnic-

1 Jednalo se o přibližně 200 i více osob (údaje se liší), které obdržely ve zrychleném řízení povolení $\mathrm{k}$ trvalému pobytu. Do České republiky byli dopravováni armádním letounem, autobusem, ale také přijížděli po vlastní ose. Celá záležitost byla značně medializovaná i zpolitizovaná.

2 Rogers Brubaker (1998) uvádí termín etnomigranti s podobným významem.

3 Právě z důvodu absence diasporické př́slušnosti jsou pak etničtí návratoví migranti označováni jako potomci krajanů (diasporic descendants; Tsuda 2009), a nikoliv jako krajané (diaspora). 
ká návratová migrace naopak uvádí absenci této identifikace a vyjadřuje strategické a pragmatické jednání. Cílem je tedy zjistit, do jaké míry lze uplatnit pojmy návratová migrace/reemigrace, respektive etnická návratová migrace vůči potomkům krajanů.

Samotný termín etnická návratová migrace není samozřejmě tak jednoznačný, jak by se mohlo na základě výše uvedené definice zdát. Základním bodem však zůstává, že etnické dispozice (např. dokumenty o etnicitě předků) jsou strategicky využívány $\mathrm{k}$ migraci do země původu předků - a to ukazuje na pragmatické zájmy etnických návratových migrantů, kteří spíše než k „etnické nebo kulturní blízkosti“ s národem v zemi imigrace vzhlížejí k ekonomické prosperitě, $\mathrm{k}$ lepším životním podmínkám a k rozvinutému trhu práce v této zemi (Fox 2007; Kulu - Tammaru 2000; Tsuda 2003; 2009; Waterbury 2006). Do určité míry tak mohou být etničtí návratoví migranti považováni i za pracovní migranty (Fox 2003; 2007; Skrentny et al. 2007; Tsuda 2009; Waterbury 2006; 2014). Klíčovým bodem však je, že i bez diasporického vědomí jsou jejich etnické dispozice předpokladem „snazší“ migrace, protože politiky určitých států preferují imigraci krajanů díky jejich původu, a nabízí jim v př́ípadè imigrace i určité benefity (napřr. získání trvalého pobytu v př́padě České republiky), což určuje sílu etnické návratové migrace (Fox 2003; 2007; Iglicka 2001; Joppke 2005; Joppke - Rosenhek 2009; Kulu - Tammaru 2000; Tsuda 2009; Skrentny et al. 2007; Waterbury 2014). Na druhou stranu to může být považováno i za podvod vůči oficiální politice státu právě kvůli ztrátě etnického vědomí (Iglicka 2001).

Kromě atraktivní ekonomiky a preferenční imigrační politiky konkrétních států však nabízejí badatelé i další aspekty, které tento migrační proud vysvětlují. V zemi imigrace tak mohou mít svou působnost i sociální sítě (Fox 2007; Kulu - Tammaru 2000) a svou roli hraje také možnost kvalitního vzdělání pro děti (Kulu - Tammaru 2000). Naopak ze země narození může tyto migranty „vyhánět" etnická perzekuce (Joppke 2005; Kulu 2002; Tsuda 2009), environmentální změny (Kulu 1998), ale zejména špatné ekonomické podmínky (Fox 2007; Joppke - Rosenhek 2009; Tsuda 2009). Právě posledně jmenovaný aspekt je v př́padě etnické návratové migrace vnímán jako nejčastější prríčina odchodu ze země narození (Tsuda 2003).

Konkrétně se pojem etnická návratová migrace užívá především ve spojení s potomky židovských nebo německých krajanů ze Sovětského svazu/ Ruska (Brubaker 1998; Markowitz - Stefansson 2004; Tsuda 2009) nebo s potomky polských krajanů z post-sovětského prostoru (Iglicka 2001). Dále se používá i pro osoby srbského, bulharského nebo chorvatského původu z konkrétních balkánských zemí (Waterbury 2014), pro osoby 
řeckého, finského, kazašského nebo ruského původu z post-sovětských zemí (Brubaker 1998) nebo pro osoby japonského původu z Brazílie nebo Peru (Tsuda 2003).

V momentě „užití " potenciálu etnické návratové migrace je značný rozdíl mezi evropskými a asijskými zeměmi. $\mathrm{V}$ asijských zemích může být princip etnické návratové migrace intencionálně využit imigračním státem za účelem získání vzdělaných jedinců, což je také př́klad Jižní Koreje a Taiwanu, ale už např́íklad Japonsko se snaží získat málo kvalifikované osoby pro práci v závodech (Tsuda 2003). Evropské země jsou pak zaměřené na romantizující pohled (např. na spojení „krve“ národa), a intencionální využití tohoto migračního proudu se jeví jako méně podstatné, přestože reálně existuje např́klad v př́padě Mad'arska (Skrentny et al. 2007; Waterbury 2006).

$\mathrm{V}$ tomto článku se budu věnovat migraci mladší generace potomků krajanů ze západní Ukrajiny do České republiky, konkrétně z Rivnenské oblasti (s krajským městem Rivne) a Volyňské oblasti (s krajským městem Luck), ale také migraci mladší generace potomků krajanů z jižní Moldávie do České republiky, konkrétně z obce Holuboje (rumunsky označována jako Huluboaia) a z města Cahul (ruským označením Kagul a ukrajinským Kahul). Mladší generace potomků krajanů z obou států je vymezená věkem do 30 let, její prŕslušníci jsou již několikátými potomky prvních českých přistěhovalců a vlivem urbanizace, smíšených manželství, disperzního osídlení a mobilitou za vzděláním a za prací mají určité dispozice ke ztrátě českého etnického vědomí. Také však na ně dopadají emigrační tendence kvůli neúspěšnému přechodu Ukrajiny a Moldávie na tržní hospodářství po rozpadu Sovětského svazu (1991), přičemž Česká republika je v obou těchto zemích obecně nahlížena jako jedna z cílových zemí migrace. Zde je nutné podotknout, že mladší generace potomků krajanů z Moldávie je na rozdíl od svých protějšků z Ukrajiny méně začleněna $\mathrm{v}$ moldavské společnosti $\mathrm{z}$ důvodu relativní endogamii české komunity, spíše regionální mobilitě a slabší urbanizaci.

Důležitým stimulem pro sepsání tohoto článku je však představení metodologického př́stupu návratové migrace/reemigrace a etnické návratové migrace, a $\mathrm{z}$ empirického výzkumu jsou tak - $\mathrm{z}$ důvodu omezeného rozsahu článku - použity jen relevantní informace. Celý původní výzkum včetně důsledné interpretace získaných dat je uveden jinde (Jirka 2018).

V první části článku popíśu metodologii výzkumu, následně se budu věnovat pojmům návratová migrace/reemigrace $\mathrm{v}$ českém prostředí. V empirické části uvedu, jak sami participanti z řad mladší generace potomků krajanů interpretují své rozhodování ohledně migrace do České republiky. Na závěr pak uvedu, do jaké míry lze vůči mladší generaci po- 
tomků krajanů ze západní Ukrajiny a z jižní Moldávie uplatnit principy návratové migrace/reemigrace nebo principy etnické návratové migrace.

\section{Metodologie výzkumu}

Kvalitativní antropologický výzkum s použitím metody multi-sited ethnography (Falzon 2009) proběhl v letech 2012-2018 v Rivnenské a Volyňské oblasti (na západní Ukrajině) a v České republice. V Rivnenské oblasti bylo pro výzkum stěžejní město Dubno se zdejším krajanským spolkem Dubenské české sdružení Stromovka. Výzkum však probíhal také ve městě Rivne s krajanským spolkem Česká beseda a v přilehlých vesnicích (Molodavo, Myrohošča, Hlyns'k), popřípadě v menších městech (Zdolbuniv). Ve Volyňské oblasti probíhal výzkum ve městě Luck, kde sídlí krajanský spolek Sdružení Čechů „Matice Volyňská“. Spíše okrajově pak byla do výzkumu zařazena také Lvovská oblast, protože ve Lvově byl proveden rozhovor s původním obyvatelem obce Hlyns'k. $V$ př́padě mladší generace potomků krajanů z jižní Moldávie se jednalo o výzkum zaměřený na participanty narozené $\mathrm{v}$ obci Holuboje nebo $\mathrm{v}$ nedalekém městě Cahul, přičemž participanti často byli členy místního krajanského Českého spolku Novohrad. Stěžejní část výzkumu mladší generace potomků krajanů z Rivnenské a Volyňské oblasti probíhala na Ukrajině, ovšem v př́padě participantů z jižní Moldávie probíhal terénní výzkum pouze v České republice. V České republice byl s participanty z obou zemí proveden výzkum ve městech Praha, Brno, Hradec Králové, Rychnov nad Kněžnou, Uničov a Žatec.

Metodou výzkumu byly polostrukturované rozhovory, ve kterých byl zachycen vztah participantů k českému prostředí, jejich sociální a ekonomická situace $\mathrm{v}$ zemi narození, vztah k českým předkům, jejich interpretace ohledně legálních (i nelegálních) možností překonání restriktivní imigrační politiky České republiky a ohledně jejich postmigrační situace v České republice (pokud nebyl rozhovor proveden na Ukrajině v premigrační fázi). Celkem bylo pořízeno jedenáct rozhovorů s participanty z mladší generace potomků krajanů z Rivnenské a $\mathrm{z}$ Volyňské oblasti a pět rozhovorů s participanty z mladší generace potomků krajanů z Holuboje a z Cahulu (viz Tabulka č. 1). Rozhovory byly pořízené také s participanty ze střední generace (30-60 let) a starší generace (60 let a více) potomků krajanů, v tomto př́padě se však jednalo pouze o participanty z Rivnenské a Volyňské oblasti. Celkem bylo pořízeno osm rozhovorů s participanty ze střední generace a patnáct rozhovorů s participanty ze starší generace. Tyto rozhovory sloužily pro tento článek spíše ke srovnání, tedy ke zjištění, do jaké 
míry jsou participanti z mladší generace strukturálně, sociálně, etnicky i kulturně začleněni v zemi svého narození ve srovnání se střední a starší generací. ${ }^{4}$

V průběhu výzkumu se ukázalo, že diktafon byl často negativním prvkem, protože někteří participanti nechtěli své narace zaznamenávat kvůli obavám z př́padného zneužití. Důležitým prvkem proto bylo zúčastněné pozorování a terénní deník, kam byly kromě poznámek z terénního výzkumu zaznamenávány také poznámky z neformálních setkávání s participanty (např. během nakupování nebo návštěv restauračních zařízení). Neformální setkání často pomáhala objasnit důležité souvislosti, které mohly být během rozhovorů opomenuty, a díky tomu vyšly najevo i některé nové skutečnosti (zejména pokud participanti referovali o jiných účastnících výzkumu). Vzhledem k mé aktivní znalosti ukrajinského jazyka nebylo problematické uskutečnit rozhovory i s mladšími participanty ze západní Ukrajiny, kteří český jazyk neovládali. Mladší generace potomků krajanů z jižní Moldávie (až na jednoho participanta) pak znala český jazyk díky dlouhodobému pobytu v České republice.

Obecně bychom mohli jako potomky krajanů označit všechny potomky prvních imigrantů, kteří přišli na dané území. Potomky krajanů $\mathrm{v}$ př́padě tohoto článku budeme definovat jako jedince, kteří mají ve svém rodokmenu předky původem $\mathrm{z}$ Čech, ale budeme se věnovat primárně participantům $\mathrm{z}$ řad mladší generace potomků krajanů (do 30 let), přičemž takto definovaní participanti z Rivnenské a Volyňské oblasti mají jednoho českého prarodiče nebo praprarodiče, zatímco participanti z Holuboje nebo z Cahulu mají jednoho českého prarodiče, popř́padě i rodiče. Tyto své předky sami participanti identifikují jako nositele české etnicity, anebo je česká národnost těchto předků zapsána ve starých osobních dokumentech. Je nutné ještě podotknout, že situace mladší generace potomků krajanů ze západní Ukrajiny a z jižní Moldávie ${ }^{5}$ je odlišná než situace u jejich protějšků $\mathrm{v}$ jiných regionech. Např́klad mladší generace potomků krajanů ze zemí západní Evropy nemusí mít národnost předků zapsanou ve starých osobních dokumentech, a také jejich genealogická situace může být odlišná (viz Harpaz 2015).

4 Uvedené rozhovory byly původně provedené pro disertační práci, a z tohoto důvodu je vyšší počet participantů ze střední a starší generace. Pro tento článek jsou však zásadní participanti z mladší generace.

5 Je nutné uvést, že se starší generace na západní Ukrajině i v jižní Moldávii stále vyjadřuje $\mathrm{v}$ termínech diasporické sounáležitosti $\mathrm{k}$ českému prostředí. 


\section{Termíny návratová migrace/reemigrace a jejich význam}

Termíny návratová migrace/reemigrace můžou mít v českém prostředí mnoho různých definic. Jednotícím prvkem těchto definic je, že jsou vždy spojené s návratem do původní lokality, která je často ztotožněna s teritoriem státu. Stanislav Brouček uvádí, že pojem návratová politika je spojen „s návratem lidí zpět na pưvodní místo, z něhož před časem odešli“ (Brouček 2014: 14). Termín reemigrace ${ }^{6}$ Lenka Šolcová chápe jako „vystěhování (obyvatel) z určité oblasti a následně, po určitém obdobi, kjejich návratu zpèt do zdrojové země" (Šolcová 2012: 152). Podle Jany Noskové se termín reemigrace vztahuje na „navrátivši se obyvatele českého (a slovenského) původu, kteř́ měli státní občanstvíjiného státu“ (Nosková 2007: 43). ${ }^{8}$ Další autoři, kteří píśí o reemigraci krajanů, pak návratovou migraci a reemigraci nijak nedefinují a nijak ji teoreticky nerozebírají (např. Vaculík 2002; Heroldová 1989; 1992 atd.).

Je patrné, že tyto termíny byly ovlivněné specifickým teoretickým a hodnotovým porozuměním (Nešpor 2002) a lze uvést, že pojmem návratový migrant/reemigrant jsou označovány osoby s českým původem - a právě díky tomuto původu je jim přisuzována identifikace s českým národem (viz Skalník 1990). Badatelé tak můžou hovořit o „intenzioním prožívání pocitu sounáležitosti s př́slušníky vlastního etnika, s Čechy v historické vlasti, které vnímají jako silnou skupinu téže národnostní identity, jako určitou oporu, resp. zázemí" (Dluhošová 1996: 61), anebo o tom, že „etnický pưvod, ke kterému se tito migranti hlásí, bývá obvykle shodný s etnicitou autochtonní populace v imigrační lokalitě" (Lozoviuk 2000: 96). Pokud jde o krajany, jde o „etnické Čechy, tj. Čechy žijící za hranicemi svého národa“ (Heroldová 1989). Podobné teze bychom našli i jinde ${ }^{9}$ (např. Drbal 2004 atd.).

Toto hodnotové porozumění je spjaté s československou etnografií (národopisem), která byla významně ovlivněna sovětskou teorií etnosu (viz Bromlej 1980; Jakoubek 2016: 68-69) a ještě dříve německým prostředím

6 Ve vztahu k poválečné reemigraci se někdy používá také termín repatriace. Repatriace znamená organizované vracení osob do státu (vlasti), které mají státní občanství tohoto státu (Nosková 2007).

7 Závorky v původním textu absentují a byly přidány autorem článku.

8 Také Zdeněk Nešpor, který jinak silně kritizuje metodologickou rovinu výzkumů reemigrace, kalkuluje s termínem reemigrace jako s návratem - „návratu ke ,staré“ identitě“ nebo k „přijetí ,starých“ sociálních rolí“ (2002: 34).

9 Uvedené teze obsahují samozřejmě i rozdíly, protože epistemologicky odlišná je „sounáležitost“ a „shodnost“ etnicity nebo „češství za hranicemi národa“, ovšem stále je naplněn určitý moment př́slušnosti/sounáležitosti k českému národu. 
(Lozoviuk 1998) a své důsledky má do dnešních dní. ${ }^{10}$ Podle př́stupu teorie etnosu se údajně uchovává sounáležitost s národem i nezávisle na tom, zda se jedná o první imigranty nebo o jejich potomky. Národnost sice může podléhat $\mathrm{v}$,jinonárodním prostředí změně, např́klad jazykově (Šatava 1989), ale přináležení k národu. Díky původu zůstává nezměněné a je v podstatě jedno, jestli se hovoří o prvních imigrantech nebo o jejich dětech (jak je patrné i u autorek Ivy Heroldové, Heleny Dluhošové aj.). Problematické je, že krajanům je sounáležitost $\mathrm{s}$ národem přisuzována zvenčí z akademického prostředí a slouží jako prvek kategorizace. V tomto momentě se dostáváme $\mathrm{k}$ metodologické problematice termínů reemigrace a návratová migrace, protože všichni krajané, bez ohledu na to, zda figurují jako první imigranti nebo jako potomci krajanů, jsou kategorizováni v termínech sounáležitosti s českým národem (viz např. Valášková 1992). V př́padě reemigrace jsou tak označováni jako „navrátivší se“, protože údajně mají pocitovat přináležitost $\mathrm{k}$ českému národu, aniž by bylo zkoumáno, nakolik se s tímto označením sami ztotožňují. Identifikace $\mathrm{s}$ tímto označením je snad víceméně př́slušná $\mathrm{v}$ př́padě např́íklad reemigrantů, kteř́ utíkali z Československa v roce 1948 a po roce 1989 se vrátili. Sporné je neproblematicky spojovat identifikaci s národem $\mathrm{v}$ př́padě již dalších potomků krajanů, jak to činí mj. Nad’a Valášková (1992; 2014), Andrej Sulitka (2014), Jaroslav Vaculík (2002; 1989), Jana Nosková (2007), Iva Heroldová (1992) nebo Pavel a Vít Jančákovi (2007), ačkoliv i zde musíme přiznat určitý rozdíl mezi reemigrací z roku 1945 a pozdější „reemigraci“" po roce 1989. Situace krajanských enkláv totiž byla v roce 1945 odlišná (např. se jednalo o celé české vesnice) než po roce 1989 (kdy se často jedná o disperzně rozmístěné jedince v nečeské majoritní společnosti).

Záleží samozřejmě na více faktorech vždy specifických pro konkrétní krajanskou komunitu a nechci naznačovat, že by se potomci krajanů za žádných okolností nemohli s českým národem identifikovat. Mým záměrem je uvést, že badatelé při použití termínů návratové migrace/reemigrace přisuzují - často i nereflektovaně - identifikaci s českým národem i potomkům krajanů, aniž by si uvědomovali důležitost rozdílu mezi nimi a prvními imigranty. Za př́klad lze uvést výzkum reemigrantů z jihoukrajinské Novgorodkivky. Autorka výzkumu uvádí, že u potomků krajanů již proběhlo začlenění do ukrajinské společnosti, a po reemigraci tak měli problémy s adaptací v České republice. Ovšem i navzdory tomu jim při-

10 Účelem tohoto článku není analyzovat vlivy německého a sovětského prostředí na československou etnografii. $V$ prŕpadě zájmu o tuto problematiku lze čtenáře odkázat na práce Petra Lozoviuka (1998), nebo na sborníky Češi $\mathrm{v}$ cizině. 
suzuje identifikaci s českým národem zcela neproblematicky a nereflektovaně (Bělohradská 2008).

Dostáváme se tak do situace, že mnoho badatelů pracuje s předpokladem identifikace potomků krajanů s českým národem. Nebo přinejmenším tuto skutečnost nijak nerozvádí, neanalyzuje ji a vnímá ji jako samozřejmost. Činí tak Zdeněk Uherek, když uvádí, že pro potomky krajanů je Česká republika „opuštèný domov", „stará vlast" nebo "místo svého pưvodu“ (2014: 174), ale neanalyzuje ji ani Jaroslav Vaculík, když uvádí, že potomci krajanů jsou zasaženi „myšlenkou návratu do staré vlasti“ (2002: 9). Problematické používání slova reemigrace ve vztahu k potomkům krajanů naznačuje pouze Petr Lozoviuk (2005) a Vladislav Günther (2016), ale ani tito autoři se uvedené problematice dostatečně nevěnují.

Jiná je situace $v$ Německu, kde došlo $\mathrm{k}$ tomu, že se o etnicitě a návratové migraci diskutovalo v př́padě tzv. Aussiedler a vyvstala otázka, zda jsou navrátilci z Ruska etnicky podobní nebo vzdálení současným Němcům (napřr. Faist 1993). V českých sociálních vědách však podobná diskuse nikdy neproběhla a termíny návratová migrace/reemigrace zůstaly de facto prostředkem pro přisuzování etnické afinity i u potomků krajanů. Jak by však reagovali samotní participanti z řad mladší generace potomků krajanů?

\title{
Návrat nebo etnická návratová migrace. K jaké „kategorii“ by inklino- vala mladší generace potomků krajanů?
}

Přejdeme-li od významů termínů k naracím participantů a participantek, pak lze uvést následující citaci jedné z nich:

\begin{abstract}
„Fá jsem prijiela do Česka a tady jsem se chtěla zapojit to nějakých organizací. Takjsem hodnězačala hledat na internetu. Na internetu mají všichni stránky (...). Já jsem tam [do Olomouce] jela a fakt to jsou takové organizace, které pomáhají dètem, třeba charita. (...). U nás [na Ukrajině] nèco takového není. To je prostě zkažený stát. (...) Tady jsme jezdili po nějakých městech a já jsem viděla, že tady se lidi mají prostè lépe. "1ㅡㄹ
\end{abstract}

Další participantka také hovoř́ o rozdílech mezi Českou republikou a Ukrajinou:

11 Participantka M. S., nar. 1996, 23. 2. 2015, Uničov, Česká republika. 
„Já ríḱám, že jsme odjeli do Rychnova, protože chceme něco trošku lepš̌́ho. Chceme [Chtěli jsme] prostě lepši trošičku, protože ve srovnání s Ukrajinou, to možná všichni víme, možná to nebude [nebylo] něco takového [jako na Ukrajině]. Prostě myslíme [jsme si mysleli], že tam bude něco lepšího. " ${ }^{\text {"2 }}$

Obě participantky vnímají české prostředí v porovnání s ukrajinským jako perspektivnější. Také ostatní participanti a participantky se vyjadřují o České republice pozitivně v porovnání s Ukrajinou a s Moldávií. Zdůrazňují názory o lepším školském systému, lepším chování českých obyvatel, přívětivějším jednání státu i o možnosti zábavy pro mladé lidi (viz také Šolcová 2012; Bělohradská 2008 atd.). Oproti tomu byly Ukrajina i Moldávie nezřídka hodnoceny negativně, a to zejména s odkazem na ekonomické problémy (např. malé platy), sociální nesnáze (např. neexistence stř̌ední trí́dy) nebo strukturální potíže (např. široce rozšířená korupce). U participantů a participantek se tak primárně objevuje snaha odejít z málo prosperující země do perspektivnější, a právě toto je klíčový znak etnické návratové migrace (Tsuda 2009), přičemž takto definovaný kalkul ze strany potomků krajanů - který by mohl být primárně a pouze orámován př́vlastky jako strategický, racionální, pragmatický i klíčový by návratová migrace/reemigrace zřejmě odmítla, maximálně by postavila výše uvedené důvody po bok identifikace s českým národem. Toto by etnická návratová migrace ale neučinila, protože nehovoří o identifikaci s národem jako o důvodu imigrace do země předků.

Sami participanti a participantky z Rivnenské a Volyňské oblasti navíc tuto identifikaci vůbec neartikulují a ani se o ní nijak nezmiňují, zatímco ti z Moldávie se na tuto identifikaci odvolávají. ${ }^{13}$ Je zde tak patrný rozdíl mezi oběma komunitami, který je dán historickými, respektive sociálními

12 Participantka K. P., nar. 1996, 1. 8. 2013, Dubno, Ukrajina.

13 Určitým vodítkem $\mathrm{k}$ identifikaci nebo $\mathrm{k}$ neidentifikaci s českým národem může být i skutečnost, že se výzkumy návratové migrace/reemigrace prováděly často až po př́chodu krajanů do České republiky (a někdy až dlouho po př́íchodu) a doba pobytu, respektive časový interval mezi př́chodem krajanů a výzkumem dovoluje konstruovat postoje a důvody migrace směrem $\mathrm{k}$ diasporické formě (Šolcová 2012). Také v tomto výzkumu byly rozhovory s mladší generací potomků krajanů z jižní Moldávie provedeny až po několika letech jejich pobytu v České republice (konkrétně po 1-6 letech pobytu, v jednom př́padě až po 14 letech pobytu), a to možná mělo vliv na jejich uvažování. Postoje se tak mohly více etablovat do formy sounáležitosti s českým prostředím v kontrastu s postoji protějšků z Rivnenské a Volyňské oblasti, kteří tuto sounáležitost nevyjadřovali, a se kterými byly uskutečněny rozhovory ještě na Ukrajině, v průběhu migrace nebo krátce po ní. 
okolnostmi (tj. relativní endogamie české komunity v jižní Moldávii, spíše regionální mobilita a slabší urbanizace jak v období Sovětského svazu, tak nezávislé Moldávie). Na otázku ohledně subjektivního etnického vědomí („Kým se cititte být? Čechem/Češkou nebo Ukrajincem/Ukrajinkou?") odpovídali participanti a participantky ze západní Ukrajiny následovně: „Jako byli jsme, my jsme si uvédomovali, že jo, jsem Ukrajinka. "14 Nebo: „Myslím, že to je na pưlku, ale protože sem více života bydlel tady na Ukrajině, už mám vétš́ vztah s Ukrajinou. “55 Identifikace s českým národem není v př́padě mladší generace potomků krajanů z Rivnenské a Volyňské oblasti zmiňována, a naopak je uváděna etnická afiliace $\mathrm{k}$ ukrajinské majoritě, což je další typický znak etnické návratové migrace, ale také důležitý rozdílový bod v porovnání s návratovou migrací/reemigrací.

Jednotícím prvkem návratové migrace/reemigrace a etnické návratové migrace je naopak určitá kalkulace mladší generace potomků krajanů s imigrační politikou České republiky vůči krajanům. Participanti uváděli hned několik důvodů pro odjezd do České republiky, ale relativně př́znivá česká imigrační politika vůči krajanům (přestože se jedná spíše o vedlejší efekt než o záměr české migrační politiky) pro ně byla velice důležitým bodem. Autoři zkoumající etnickou návratovou migraci opět hovoří o př́znivé imigrační politice konkrétních států vůči potomkům krajanů a uvádějí, že díky imigrační politice a předkům potomků krajanů je etnická návratová migrace do země původu předků usměrňována (Tsuda 2009). Tomu často předchází státem vydávaná potvrzení ohledně př́slušnosti k diaspoře (např. duální občanství, denizenship, quasi-citizenship, v př́padě České republiky se jedná o PPKK, tedy o potvrzení o př́slušnosti k české krajanské komunitě $\mathrm{v}$ zahraničí), která slouží pro získání trvalého pobytu v zemi imigrace nebo $\mathrm{k}$ jiným užitečným výhodám. V př́ípadě České republiky může i potomek krajanů získat v České republice trvalý pobyt do šesti měsíců od podání žádosti, pokud je držitelem potvrzení o př́slušnosti k české krajanské komunitě v zahraničí. Jedná se o značný benefit určující sílu a směr etnické návratové migrace, protože bez potvrzení o př́slušnosti k české krajanské komunitě v zahraničí lze na trvalý pobyt dosáhnout až po pěti letech nepřetržitého pracovního pobytu, respektive po deseti letech nepřetržitého studijního pobytu v České republice. V Tabulce č. 1 je uvedeno, kolik participantů má potvrzení o př́slušnosti k české krajanské komunitě v zahraničí společně s trvalým pobytem v České republice. Jde zde důležité vysledovat, že držitelé PPKK jsou často zároveň držitelé trvalého pobytu v České republice, což potvrzuje pozitivní korelaci mezi získáváním PPKK a trvalého pobytu.

14 Participantka H. P., nar. 1996, 1. 8. 2013, Dubno, Ukrajina.

15 Participant M. T., nar. 1985, 27. 7. 2013, Dubno, Ukrajina. 
Na základě rozhovorů pak bylo u devíti participantů získání PPKK i trvalého pobytu proklamovaným pragmatickým a strategickým kalkulem (zatímco u pěti byla vyjadřovaná sounáležitost s českým národem).

Tabulka č. 1

\section{Participanti}

\section{Datum narození \\ Místo narození / pohlaví}

K. P., 1996

H. P., 1996

J. I., 2000

J. A., 1991

E. Y., 1985

M. U., 1998

M. T., 1985

Z. K., 1991

V. M., 1985

R. A., 1985

O. P., 1994

N. R., 1992

K. S., 1984

O. P., 1987

P. S., 1991

Holuboje (Moldávie) / žena

L. K., 1985

Dubno (Ukrajina) / žena

Dubno (Ukrajina) / žena

Dubno (Ukrajina) / žena

Lviv (Ukrajina, ale žila

v Lucku) / žena

Luck (Ukrajina) / žena

Luck (Ukrajina) / muž

Dubno (Ukrajina) / muž

Dubno (Ukrajina) / žena

Dubno (Ukrajina) / muž

Luck (Ukrajina) / žena

Luck (Ukrajina) / muž

Holuboje (Moldávie) / žena

Holuboje (Moldávie) / muž

Holuboje (Moldávie) / žena

Holuboje (Moldávie) / muž
PPPK/trvalý pobyt v České republice / Příchod do České republiky

PPKK i trvalý pobyt / 2010

PPKK i trvalý pobyt / 2010

Ne (snazší byla jiná cesta) / 2014

PPKK i trvalý pobyt / 2015

PPKK i trvalý pobyt / 2015

$-/ 2017$

PPKK i trvalý pobyt / cirkulární migrace

PPKK i trvalý pobyt / 2014

PPKK i trvalý pobyt (artikuloval identifikaci s českým národem) / 2010

PPKK i trvalý pobyt / ?

PPKK i trvalý pobyt / 2015

PPKK i trvalý pobyt (artikulovala identifikaci s českým národem) / 2012

PPKK i trvalý pobyt / 2015

PPPK i trvalý pobyt (artikulovala identifikaci s českým národem) / 2013

studentské vízum (artikulovala identifikaci s českým národem) / 2016

PPKK i trvalý pobyt (artikuloval identifikaci s českým národem) / 2006 
V níže uvedené Tabulce č. 2 lze pak vidět počet úspěšných žadatelů o potvrzení př́slušnosti ke krajanské komunitě v zahraničí v letech 20062016. Z tabulky je patrné, že v př́padě celosvětové ekonomické krize (v roce 2008 i poté) a v případě války na východní Ukrajině (od roku 2014) mělo snahu získat potvrzení o příslušnosti ke krajanské komunitě více osob z Ukrajiny. Díky příznivé české imigrační politice vưči krajanům tak mohli krajané získat trvalý pobyt v České republice po získání potvrzení o příslušnosti k české krajanské komunitě v zahraničí, a vzhledem k podmínkám v jejich zemi narození lze s největší pravděpodobností i v tomto případě odkázat na strategický, pragmatický nebo instrumentální kalkul, ačkoliv to zůstává pouze naším předpokladem.

Tabulka č. 2 Počet úspěšných žadatelů o PPKK z Moldávie a Ukrajiny

\begin{tabular}{llllllllllll}
\hline & 2006 & 2007 & 2008 & 2009 & 2010 & 2011 & 2012 & 2013 & 2014 & 2015 & 2016 \\
Moldávie & 7 & 33 & 56 & 21 & 10 & 14 & 0 & 5 & 6 & 4 & 4 \\
Ukrajina & 82 & 163 & 208 & 154 & 304 & 154 & $\mathrm{X}$ & 54 & 175 & 357 & 266 \\
\hline
\end{tabular}

Zdroj: Oddělení zvláštního zmocněnce pro krajanské záležitosti, data poskytla pracovnice Eva Novotná. Nárůst i pokles žadatelů v závislosti na ekonomické a politické situaci je $\mathrm{v}$ tabulce jasně viditelný $\mathrm{s}$ výjimkou roku $2009 \mathrm{v}$ př́padě Moldávie i v prípadě Ukrajiny. Čísla je tedy nutné sledovat s určitou obezřetností.

Někteří participanti a participantky pak obecně potvrzení o př́íslušnosti k české krajanské komunitě v zahraničí spojovali přímo s imigrací do České republiky:

„Začala jsem řešit otázku, co dále se životem. Fá ani ted'v tom nemám úplnějasno, že ano, a takjsem si říkala, že zkusím udělat ten status krajana a možná si zažádat o trvalý pobyt. Na základě toho, že maminka je Češka. (...) Musela jsem na ambasádě, jinak to nešlo. "16

Tento prvek byl často uváděn i těmi participanty/participantkami, kteří hovořili o jiných potomcích krajanů:

„Maminka byla Češka nebo jak tam. Nebo naopak. Ale ona se holka nebo kluk z rodiny zapsal jako Kazach. On byl v Kazachstánu, žil a chtěl mít tu zelenou cestu, aby mohl jút dál, dál, dál. A když vidí, že

16 Participantka N. R., nar. 1992, 2. 2. 2014, Praha, Česká republika. 
nic není a žádná perspektiva, tak si myslí: „Tak já se vrátím k mamince, protože tam je nějaká výhoda z toho, že já se tam můžu dostat." Rozumiš, takhle to dèlajį " "17

Podobné jednání je předpokladem etnické návratové migrace, a tím se tento př́stup razantně liší od návratové migrace/reemigrace, která by žádost participantů o potvrzení o př́slušnosti k české krajanské komunitě v zahraničí zřejmě interpretovala jako akt sounáležitosti s českým národem. Jak nám však ukazují výše uvedené citace z rozhovorů, nelze vždy chápat jednání potomků krajanů pomocí nacionalizující perspektivy, protože někdy nejsou preferenční hodnoty spojitelné s př́slušností $\mathrm{k}$ národu, a přesto se etnické dispozice využívají za účelem migrace, což vytváří prostor pro etnickou návratovou migraci. $Z$ toho vyplývá i skutečnost, že pro některé participanty/participantky z tohoto výzkumu nemusí být Česká republika reálnou domovinou a tím i cílovou zemí migrace, ale spíše tranzitní zemí, která díky možnosti získání trvalého pobytu umožňuje vycestování do dalších států Evropské unie. Pro jednu participantku v tomto výzkumu se tak již stalo domovem Německo a pro druhou Anglie - Česká republika byla pro ně pouze tranzitní zemí.

Vrátíme-li se k pojmům návratová migrace/reemigrace a etnická návratové migrace, pak by mladým participantům z Ukrajiny spíše konvenoval druhý př́stup. První př́stup totiž přisuzuje potomkům krajanů identifikaci s národem, a druhý prístup podobná nacionalizující pojetí naopak marginalizuje. Druhý př́stup zároveň vyzdvihuje otázku strategického jednání potomků krajanů a možnost získat ekonomické benefity v zemi imigrace díky využití etnických předků (Joppke - Rosenhek 2009; Fox 2007; Iglicka 2001; Tsuda 2009; Waterbury 2014; Skrentny et al. 2007; Kulu - Tammaru 2000), což je patrné v př́padě mladých participantů z Rivnenské a Volyňské oblasti.

\section{Závěr}

Čeští badatelé často spojují návratovou migraci/reemigraci potomků krajanů s údajnou identifikací s českým národem. Ovšem tento nacionalizující předpoklad může marginalizovat skutečnost, že potomci krajanů již nemusí artikulovat sounáležitost s českým národem kvůli svému progresivnímu začlenění v zemi narození, a přesto se můžou odhodlat k mi-

17 Participantka N. G., nar. 1954, 5. 4. 2012, Dubno, Ukrajina. 
graci do České republiky díky př́větivé imigrační politice vůči krajanům. Nacionalizující rétorika dopadající na potomky krajanů je někdy spíše chimérou (viz také Pavlásek 2011a; 2011b; 2012; Jakoubek 2010; 2015 ${ }^{18}$ ). $\mathrm{V}$ př́padě získání potvrzení o př́slušnosti k české krajanské komunitě v zahraničí a následně i trvalého pobytu v České republice lze tak při absenci identifikace s českým národem hovořit o etnické návratové migraci.

Tím nechci tvrdit, že by čeští autoři kalkulující s návratovou migrací/ reemigrací opomíjeli ekonomické, materiální nebo sociální důvody migrace krajanů do České republiky, anebo že si nebyli vědomi preferenční imigrační politiky českého státu vůči krajanům. Všechny tyto prvky jsou však spojeny s přesvědčením o identifikaci potomků krajanů s českým národem, a tím se mírní označování strategického a instrumentálního jednání ve prospěch nacionalizujících prvků. Právě př́slušnost $\mathrm{k}$ českému národu je jako důvod migrace do České republiky často (alespoň z pohledu politiky a veřejného zájmu) označována jako „morálnější “ než strategické a instrumentální jednání migrantů. Termíny návratová migrace/reemigrace tak můžou sloužit politickému i veřejnému zájmu, ale metodologicky je tento př́stup problematický a je otázkou, jestli se nejedná spíše o kategorii praxe (Brubaker 2006). Pokud však absentuje sounáležitost k českému národu u potomků krajanů, pak nelze uplatnit termíny návratová migrace/reemigrace. Naopak je nutné hledat jiný rozměr migrace do České republiky, který nabízí právě termín etnická návratová migrace.

Je však nutné uvést, že termín etnická návratová migrace nemůže být aplikovatelný na všechny potomky krajanů. Vždy záleží na strukturálním, ekonomickém a sociálním ukotvení dané krajanské komunity, protože někde žijí krajané kompaktněji a více endogamně, a jinde žijí spíše disperzně a exogamně. $\mathrm{Z}$ toho vyplývá i jejich specifická identitární rovina. Termín etnická návratová migrace tak nelze na potomky krajanů aplikovat plošně. Pojem etnická návratová migrace je totiž také kategorií, a proto ji nelze jednoduše vzít a použít. Důkazem mohou být mladší participanti z Moldávie, kteří by také mohli být kategorizováni jako etničtí návratoví migranti, kteř́ (nikoliv však všichni) však stále artikulují identifikaci s českým národem a termín etnická návratová migrace se na ně uplatňovat nemůže.

Kvèten 2020

18 Např. Marek Jakoubek (2010; 2015) uvažuje o strategickém a instrumentálním rozměru poválečné migrace krajanů z Vojvodova do Československa - právě to mělo být důvodem jejich migrace, nikoliv tedy „národní cítění“, na které poukazovaly československé instituce. Migrace tak byla podle něj spojena se špatnou ekonomickou situací v Bulharsku, a nikoliv s touhou návratu do země původu. 


\section{Literatura}

Bělohradská, Kateřina. 2008. Postmigrační procesy. Imigranti z jihoukrajinské Novgorodkivky v České republice. In: Uherek, Zdeněk - Korecká, Zuzana - Pojarová, Tereza (eds.): Cizinecké komunity z antropologické perspektivy: vybrané prípady imigračních skupin v České republice. Praha: Etnologický ústav AV C̆R, v. v. i.: 147-164.

Bromlej, Julian. 1980. Etnos a etnografia. Bratislava: Vydavatelstvo Slovenskej Akadémie Vied.

Brouček, Stanislav. 2014. Nová emigrace z České republiky po roce 1989 a návratová politika. In: Brouček, Stanislav - Grulich, Tomáš (eds.): Nová emigrace z České republiky po roce 1989 a návratová politika. Praha: Etnologický ústav AV ČR: 14-23.

Brubaker, Rogers. 1998. Migrations of Ethnic Unmixing in the „New Europe". The International Migration Review 32, 4: 1047-1065.

Brubaker, Rogers. 2006. Ethnicity Without Groups. Cambridge: Harvard University Press.

Cohen, Robin. 1997. Global Diasporas: An Introduction. Florence: Routledge.

Dluhošová, Helena. 1992. Stav etnicity přesídlenců z Ukrajiny v předreemigračním období. Češi v cizině 6 . Praha: Ústav pro etnografii a folkloristiku ČSAV. Národopisná knižnice: 11-14.

Dluhošová, Helena. 1996. Vystěhovalectví na Ukrajinu. Češi v cizině 9. Praha: Ústav pro etnografii a folkloristiku ČSAV. Národopisná knižnice: $48-66$.

Drbal, Alexandr. 2004. Češi na Ukrajině. Češi v cizině 12. Praha: Etnologický ústav AV ČR v Praze: 44-68.

Falzon, Marc-Anthony. 2009. Multi-Sited Ethnography, Theory, Praxis and Locality in Contemporary Research. Farnham: Ashgate.

Faist, Thomas. 1993. How to define foreigner. Universität Bremen: Center for Social Policy Research: 5-23.

Fox, John E. 2003. National Identities on the Move: Transylvanian Hungarian Labour Migrants in Hungary. Fournal of Ethnic and Migration Studies 29, 3: 449-466.

Fox, John E. 2007. From National Inclusion to Economic Inclusion: Ethnic Hungarian Labour Migration to Hungary. Nations and Nationalism 13, 1: 77-96.

Günther, Vladislav. 2016. Imigrace do Československa a Česka po druhé světové válce. In: Uherek, Zdeněk (ed.): Migrace: Historie a současnost. Ostrava: Občanské sdružení PANT: 67-92. 
Harpaz, Yossi. 2015. Ancestry into Opportunity: How Global Inequality Drives Demand for Long-Distance European Union Citizenship. Journal of Ethnic and Migration Studies 41, 13: 2081-2104.

Heroldová, Iva. 1989. Reemigrace Čechů z Rakouska po 2. světové válce. In: Češi v cizině 4. Praha: Ústav pro etnografii a folkloristiku ČSAV: 222-317.

Heroldová, Iva. 1992. Reemigrace po druhé světové válce. In: Češi v cizině 6. Praha: Ústav pro etnografii a folkloristiku ČSAV : 43-47.

Iglicka, Krystyna. 2001. Poland's Post-War Dynamic of Migration. Aldershot: Ashgate.

Jakoubek, Marek. 2010. From believers to compatriots: the case of Vojvodovo, a Czech' village in Bulgaria. Nations and Nationalism 16: 675-695.

Jakoubek, Marek. 2015. Po stopách transformací vojvodovských kolektivních identit. In: Jakoubek, Marek - Jirka, Luděk - Králová, Nela - Pavlásek, Michal - Tůma, Jiř́: Krajané. Hledání nových perspektiv. Červený Kostelec: Pavel Mervart: 17-37.

Jakoubek, Marek. 2016. Předmluva. In: Jakoubek, Marek (ed.): Teorie etnicity. Praha: Sociologické nakladatelství: 13-86.

Jančák, Pavel - Jančák, Vít. 2007. Volyňští a „černobylští“ Češi. Geografické rozhledy 16: 6-7.

Jánská, Eva - Drbohlav, Dušan. 2001. Reemigrace volyňských a Černobylských Čechů. In: Šišková, Tatjana (eds.): Menšiny a migranti v České republice. My a oni v multikulturní společnosti. Praha: Portál.

Jirka, Luděk. 2018. Migrace za lepšim životem. Etnická návratová migrace ze západní Ukrajiny. Sounáležitost s ukrajinským národem a „vytváréeni“ krajanu. Praha: Fakulta humanitních studií Univerzity Karlovy.

Joppke, Christian. 2005. Selecting by Origin. Cambridge - Massachusetts - London: Harvard University Press.

Joppke, Christian - Rosenhek, Zeek. 2009. Contesting Ethnic Migration: Germany and Israel Compared. In: Tsuda, Takeyuki (ed.): Diasporic Homecomings: Ethnic Return Migration in Comparative Perspectives. Stanford: Stanford University Press: 73-99.

Kulu, Hill. 1998. Ethnic Return Migration: An Estonian Case. International Migration 36, 3: 313-336.

Kulu, Hill. 2002. Socialization and Residence: Ethnic Return Migrants in Estonia. Environment and Planning A 34, 2: 289-316.

Kulu, Hill - Tammaru, Tiit. 2000. Ethnic Return Migration from East and the West: The Case of Estonia in the 1990s. Europe-Asia Studies 52, 2: 349-369. 
Lozoviuk, Petr. 1998. Český národopis, německá Volkskunde a evropská etnologie. K etnografické tradici studia kulturní distinkce. Studia Ethnologica 5: 89-100.

Lozoviuk, Petr. 2000. Etnické přistěhovalectví do Spolkové republiky a jeho historické, kulturní a politické pozadí. In: Lozoviuk, Petr (ed.): Evropská etnologie ve středoevropské perspektivě. Střední Evropa 16, 104-105: 96-118.

Markowitz, Franz - Stefansson, Anders. 2004. Homecomings: Unsettling Paths of Return. Maryland: Lexington Books.

Nešpor, Zdeněk. 2002. Reemigranti a sociálně sdílené hodnoty. Praha: Sociologický ústav AV ČR.

Nosková, Jana. 2007. Reemigrace a usidlování volyňských Čechů v interpretacích aktéry a odborné literatury. Brno: Ústav evropské etnologie Masarykovy univerzity.

Pavlásek, Michal. 2011a. Hledání vojvodovské pravdy ve světle probuzeneckých hnutí. Urban People/Lidé města 13, 1: 27-49.

Pavlásek, Michal. 2011b. Minulost svatohelenských nekatolíků v zajetí výkladových schémat a povahy porozumění. Český lid 98 : 81-87.

Pavlásek, Michal. 2012. Příští stanice Národní. Nastupovat! Studie o politice krajanství. In: Fatková, Gabriela - Budilová, Lenka J. - Kouba, Miroslav - Pavlásek, Michal - Štěpánek, Václav: Balkán a nacionalismus. Labyrintem nacionální ideologie. Brno: Porta Balkanica o.s.: 104-133.

Safran, William. 1991. Diasporas in Modern Societies. Myths of Homeland and Return. Diaspora 1, 1: 83-99.

Skalník, Petr. 1990. Soviet Ethnographia and the Nationalities Question. Cahiers du Monde russe et soviétique 31, 2-3: 183-192.

Skrentny, John D. - Chan, Stephanie - Fox, John E. - Kim, Denis. 2007. Defining Nations in Asia and Europe: A Comparative Analysis of Ethnic Return Migration Policy. International Migration Review 41, 4: 793-825.

Sulitka, Andrej. 2014. Politická opatření k návratu krajanů do Československa po první světové válce. In: Brouček, Stanislav - Grulich, Tomáš (eds.): Nová emigrace z České republiky po roce 1989 a návratová politika. Praha: Etnologický ústav AV ČR: 151-172.

Šatava, Leoš. 1989. České etnikum v jinonárodním prostředí. In: Češi v cizině 4. Praha: Ústav pro etnografii a folkloristiku ČSAV ve spolupráci s Československým ústavem zahraničním v Praze: 63-76.

Šolcová, Lenka. 2012. Subjektivní reflexe reemigrace černobylských přesídlenců v lokalitě Kopidlno. Český lid 99: 151-172. 
Tsuda, Takeyuki. 2001. From Ethnic Affinity to Alienation in the Global Ecumene: The Encounter Between the Japanese and Japanese-Brazilian Return Migrants. Diaspora 10, 1: 53-91.

Tsuda, Takeyuki. 2003. Strangers in the Ethnic Homeland. New York: Columbia University Press.

Tsuda, Takeyuki. 2009. Why Does the the Diaspora Return Home? The Causes of Ethnic Return Migration. In: Tsuda, Takeyuki (ed.): Diasporic Homecomings: Ethnic Return Migration in Comparative Perspectives. Stanford: Stanford University Press: 21-43.

Tsuda, Takeyuki. 2010. Ethnic Return Migration and the nation-state: Encouraging the diaspora to return 'home'. Nations and Nationalism 16, 4: $616-636$.

Uherek, Zdeněk. 2014. Návratové migrace Čechů z Ukrajiny, Běloruska a Kazachstánu do České republiky. In: Brouček, Stanislav - Grulich, Tomáš (eds.): Nová emigrace z České republiky po roce 1989 a návratová politika. Praha: Etnologický ústav AV ČR: 173-178.

Vaculík, Jaroslav. 1984. Reemigrace a usidlování volyňských Čechủ v letech 1945-1948. Brno: Ústav marxismu-leninismu Univerzity Jana Evangelisty Purkyně.

Vaculík, Jaroslav. 1989. Vznik Československa a reemigrace zahraničních Čechů. In: Češi v cizině 4. Praha: Ústav pro etnografii a folkloristiku ČSAV: 110-119.

Vaculík, Jaroslav. 2002. Poválečná reemigrace a usídlování zahraničních krajanů. Brno: Masarykova univerzita.

Valášková, Nad'a. 1992. Počátky adaptačního procesu přesídlenců z černobylské oblasti v Československu. Češi v cizině 6 . Praha: Ústav pro etnografii a folkloristiku ČSAV: 22-27.

Valášková, Nad’a. 2014. Návraty do Československa po první a druhé světové válce. In: Brouček, Stanislav - Grulich, Tomáš (eds.): Nová emigrace z České republiky po roce 1989 a návratová politika. Praha: Etnologický ústav AV ČR: 152-160.

Waterbury, Myra. 2006. Internal Exclusion, External Inclusion: Diaspora Politics and Party-Building Strategies in Post-Communist Hungary. East European Politics and Societies 20, 3: 483-515.

Waterbury, Myra. 2014. Making Citizens Beyond the Borders: Non-residental Ethnic Citizenship in Post-Communist Europe. Problems of Post-Communism 61, 4: 36-49. 